Article

\title{
Business Models for Solar Powered Charging Stations to Develop Infrastructure for Electric Vehicles
}

\author{
Jessica Robinson ${ }^{1, *}$, Gary Brase ${ }^{2, \dagger}$, Wendy Griswold ${ }^{3, \dagger}$, Chad Jackson ${ }^{4, \dagger}$ and \\ Larry Erickson ${ }^{3, *}$
}

1 Department of Chemical Engineering, Kansas State University, Manhattan, KS 66502, USA

2 Department of Psychological Sciences, Kansas State University, Manhattan, KS 66502, USA; E-Mail: gbrase@ksu.edu

3 Center for Hazardous Substance Research, Kansas State University, Manhattan, KS 66502, USA; E-Mail: griswold@k-state.edu

4 Department of Management, Kansas State University, Manhattan, KS 66502, USA; E-Mail: cjackson@k-state.edu

$\dagger$ These authors contributed equally to this work.

* Authors to whom correspondence should be addressed; E-Mails: jmrobins@live.unc.edu (J.R.); lerick@ksu.edu (L.E.); Tel.: +1-785-532-4313 (L.E.); Fax: +1-785-532-7372 (L.E.).

External Editor: Jack Barkenbus

Received: 3 August 2014; in revised form: 7 October 2014 / Accepted: 14 October 2014 / Published: 23 October 2014

\begin{abstract}
Electric power must become less dependent on fossil fuels and transportation must become more electric to decrease carbon emissions and mitigate climate change. Increasing availability and accessibility of charging stations is predicted to increase purchases of electric vehicles. In order to address the current inadequate charging infrastructure for electric vehicles, major entities must adopt business models for solar powered charging stations (SPCS). These SPCS should be located in parking lots to produce electricity for the grid and provide an integrated infrastructure for charging electric vehicles. Due to the lack of information related to SPCS business models, this manuscript designs several models for major entities including industry, the federal and state government, utilities, universities, and public parking. A literature review of the available relevant business models and case studies of constructed charging stations was completed to support the proposals. In addition, a survey of a university's students, staff, and faculty was conducted to provide consumer research on people's opinion of SPCS construction and preference of business model aspects. Results showed that $69 \%$
\end{abstract}


of respondents would be more willing to invest in an electric vehicle if there was sufficient charging station infrastructure at the university. Among many recommendations, the business models suggest installing level 1 charging for the majority of entities, and to match entities' current pricing structures for station use. The manuscript discusses the impacts of fossil fuel use, and the benefits of electric car and SPCS use, accommodates for the present gap in available literature on SPCS business models, and provides current consumer data for SPCS and the models proposed.

Keywords: emissions; kWh; solar panel; smart grid; parking; finance; payback period; electric grid; partnership

\section{Introduction}

Transportation is a major source of outdoor air pollution. Transportation accounts for one-quarter of greenhouse gas emissions and one-third of US fossil fuel consumption [1]. Carbon dioxide is one of the principal greenhouse gases, which causes global warming and climate change [2]. Eighty-five percent of the high levels of greenhouse gases in the transport sector, including carbon dioxide, can be attributed to vehicle emissions [3]. The atmospheric carbon dioxide concentrations in May 2014 reached 401.88 parts per million, 50 parts per million over the safety limit for carbon dioxide levels [2]. In order to slow the rate of climate change and to protect people's health, the amount of air pollutants must be reduced [4]. Specifically, in order to decrease carbon emissions by $80 \%$, electric power must be less dependent on fossil fuels and transportation must be electric [5,6]. Therefore, the United States and the rest of the world need to shift reliance from gasoline powered vehicles and fossil fuel based electricity generation to electric vehicles and renewable energy.

The most viable current options for making this transition are solar (and wind) power generation and increased infrastructure for electric powered transportation. Both of these are important steps in reducing carbon emissions. These two changes can be combined to maximize their impacts: solar power can be used with charging stations to generate electricity to reduce fossil fuel consumption. Many questions surround the adoption of solar power, of electric cars, and the combination of both of these new technologies together as solar powered charging stations (SPCS). However, Tesla Motors is demonstrating the feasibility of this sustainable development by constructing a network of SPCS to provide charging infrastructure in convenient locations for their electric vehicles across the nation. The purpose of the present research is to provide some initial answers to questions about the viability of solar powered charging of electric vehicles including public reception, physical logistics, business models, and economic viability. There is considerable literature related to this topic [1-66]; however, there is a need for review of business models for SPCS, which is provided in this work.

\section{Survey}

An online survey was conducted from 26 June 2014 to the morning of 7 July. The survey was designed for Kansas State University (K-State) students, staff, and faculty to provide consumer research 
of peoples' opinions on solar power, electric cars, and the installation of SPCS in campus parking lots. The survey was created on Qualtrics Survey Software and distributed through an advertisement on K-State Today, a daily email with current announcements, to staff and faculty; and through emails to students, staff, and faculty. Participants were entered into the lottery for a chance to win a \$50 gift card to the K-State Union. There were a total of 759 respondents comprised of 98 students, 192 faculty, 451 staff, 11 students and staff, five students and faculty, and two staff and faculty. Some respondents are in multiple sub-groups because they share responsibilities of both groups; i.e., someone could be a student at K-State but also work in a staff position. To provide perspective, K-State has about 6600 faculty and staff, and 24,000 students, including undergraduates and graduates [7]. The majority of the respondents were staff members (59\%). A large portion of the staff parks on campus and will remain at the university for many years; they will be more impacted by the installation of SPCS in the long-term.

Although these respondents are affiliated with a university, they are also consumers; thus their responses can at least tentatively be extrapolated to a wider consumer base and used to facilitate business model designs. The results of the survey are mentioned throughout the paper and the complete survey questions and results are included in the Appendix.

Table 1 shows how students, faculty, or staff responded to certain survey questions and allows comparison among these different groups.

Table 1. Comparison of survey results for K-State students, faculty, and staff respondents.

\begin{tabular}{lccc}
\hline \multicolumn{1}{c}{ Survey Questions } & Students & Faculty & Staff \\
\hline Most frequently drive to campus & $43 \%$ & $85 \%$ & $90 \%$ \\
Travel 2-5 miles to campus & $52 \%$ & $51 \%$ & $43 \%$ \\
Own electric cars & $0 \%$ & $3.60 \%$ & $0.20 \%$ \\
Would like to reduce the cost of commute by using electric vehicles & $73 \%$ & $69 \%$ & $58 \%$ \\
Are in favor of K-State installing SPCS & $53 \%$ & $82 \%$ & $75 \%$ \\
Would like to own an electric vehicle & $36 \%$ & $52 \%$ & $34 \%$ \\
Are more willing to invest in an electric vehicle if K-State & $26 \%$ & $44 \%$ & $26 \%$ \\
has the infrastructure & & & \\
$\begin{array}{l}\text { Believe SPCS on campus will encourage more people to purchase } \\
\text { an electric vehicle }\end{array}$ & $37 \%$ & $47 \%$ & $36 \%$ \\
\hline
\end{tabular}

Overall, faculty are the most in favor of installing SPCS, are most willing to invest in electric vehicles, and are most believing that SPCS will encourage more electric vehicle purchases. Faculty's greater interest in SPCS and electric vehicles is likely related to their greater salaries, and possibly more advanced knowledge about electric vehicles and related environmental issues.

\section{Values of Electric Vehicles}

There are several social, environmental, and economic implications associated with electric vehicles replacing internal combustion vehicles [5]. All-electric vehicles (BEVs) have no tailpipe emissions, which as a result improves air quality and lowers health risks [3]. Electric vehicles also help the nation reduce its reliance on foreign fossil fuels [1]. In addition, electric vehicles have one-tenth the number of parts that gasoline-powered vehicles have [3], thus requiring less maintenance, and saving drivers time and money. For instance, one study (cited in [3]) found that electric vehicle owners save about $46 \%$ in 
annual maintenance costs. Another economic value of electric vehicles is that energy operational costs are about one-third the fuel cost associated with internal combustion engine vehicles [5].

Table 2 shows price comparisons of electric vehicles to an average gasoline-powered car for varying distances traveled. This table compares the average cost it takes to travel a certain number of miles (one way) for an electric or gasoline powered car. The average US cost of electricity per kWh was estimated to be $\$ 0.12$ [8]. The average US price for gasoline was estimated as $\$ 3.749 /$ gallon [9]. All values used were based on 2014 data [10], but the $2013 \mathrm{mpg}$ value for the average gasoline powered car was used [11].

Table 2. Comparison of travel costs for electric vehicles and gasoline-powered cars.

\begin{tabular}{cccccccc}
\hline $\begin{array}{c}\text { Distance to } \\
\text { Destination (miles) }\end{array}$ & Tesla & $\begin{array}{c}\text { Nissan } \\
\text { Leaf }\end{array}$ & $\begin{array}{c}\text { Plug-in } \\
\text { Toyota Prius }\end{array}$ & $\begin{array}{c}\text { Ford Focus } \\
\text { Electric }\end{array}$ & $\begin{array}{c}\text { Chevrolet } \\
\text { Volt }\end{array}$ & $\begin{array}{c}\text { Average Gasoline } \\
\text { Powered Car }\end{array}$ & $\begin{array}{c}\text { Ford Focus } \\
\text { (gas) }\end{array}$ \\
\hline 10 & $\$ 0.42$ & $\$ 0.36$ & $\$ 0.35$ & $\$ 0.38$ & $\$ 0.42$ & $\$ 1.63$ & $\$ 1.21$ \\
20 & $\$ 0.84$ & $\$ 0.72$ & $\$ 1.02$ & $\$ 0.77$ & $\$ 0.84$ & $\$ 3.26$ & $\$ 2.42$ \\
30 & $\$ 1.26$ & $\$ 1.08$ & $\$ 1.77$ & $\$ 1.15$ & $\$ 1.26$ & $\$ 4.89$ & $\$ 3.63$ \\
40 & $\$ 1.68$ & $\$ 1.44$ & $\$ 2.52$ & $\$ 1.54$ & $\$ 1.80$ & $\$ 6.52$ & $\$ 4.84$ \\
50 & $\$ 2.10$ & $\$ 1.80$ & $\$ 3.27$ & $\$ 1.92$ & $\$ 2.81$ & $\$ 8.15$ & $\$ 6.05$ \\
60 & $\$ 2.52$ & $\$ 2.16$ & $\$ 4.02$ & $\$ 2.30$ & $\$ 3.83$ & $\$ 9.78$ & $\$ 7.26$ \\
Electrical & & & & & & & \\
Efficiency & 35 & 30 & 29 & 32 & 35 & N/A & N/A \\
(kWh/100 mi) & & & & & & & \\
Miles per gallon & N/A & N/A & 50 & N/A & 37 & 23 & 31 \\
Battery Range (mi) & 208 & 84 & 11 & 76 & 38 & N/A & N/A \\
\hline
\end{tabular}

The average US driver travels 33 miles each day [12]. Using Table 2, if someone drives 30 miles in total to work, five days a week for 50 weeks of the year (250 days), they would spend $\$ 1223$ on fuel for the average gasoline powered car or $\$ 288$ on electricity for a 2014 Ford Focus Electric (using US average of $\$ 0.12 / \mathrm{kWh}$ ) [8]. Thus, they would save $\$ 935$ on work commute annually by driving a 2014 Ford Focus Electric instead of the average gasoline-powered car. If someone drives 100 miles total to work a day for 250 days, they would spend $\$ 4075$ on fuel for the average gasoline powered car or $\$ 960$ on electricity for 2014 Ford Focus Electric, saving \$3115 for annual work commute fuel costs. The upfront cost of electric vehicles is often a concern of consumers, but the price of electric vehicles is decreasing with technological improvements in the battery and vehicle [1]. The 2014 Ford Focus Electric costs $\$ 35,000$, but qualifies for a $\$ 7500$ federal tax credit reducing the price to $\$ 27,500$; thus, this vehicle is $\$ 2500$ less expensive than the average 2014 gasoline-powered vehicle [13,14,57].

Four percent of survey respondents travel at least 50 miles one way to work daily. If an owner of the 2014 Ford Focus Electric needed to travel 100 miles total (50 miles one way) to and from work each day, since the battery range for the vehicle is 76 miles, they would not be able to travel the entire distance on a single charge [13]. However, the vehicle owner could make the commute if they charged their vehicle during work. Consumers already have an interest in charging at work; $64 \%$ of survey respondents would like to drive an electric vehicle and charge at work and home to decrease the cost of their commute. Thus, there is value in employers adopting a business model for SPCS. 
There are three possible charge levels (level 1-3) for electric car charging stations. Level 1 is the slowest and least expensive charging level for electric cars [15], and charges plug-in vehicles at a power level of about $2 \mathrm{~kW}$, which provides $16 \mathrm{kWh}$ in $8 \mathrm{~h}$. Since typical work-days are eight hours long, the electric vehicle could be fully recharged using this simplest charge level while sitting in the parking lot during the work day. When the vehicle owner returned home, they could plug in their vehicle again, if necessary, to recharge for their next destination. Since cars are parked about $95 \%$ of the time [16], it is logical to use this sedentary time effectively and charge electric vehicles while owners work or complete other tasks.

\section{Solar Powered Charging Stations}

Although electric vehicles reduce carbon emissions and reliance on foreign-oil, emissions issues are still present if fossil fuels are used for electricity generation. However, electric vehicles can be net zero emission vehicles if solar power generates the electricity [3]. Electric vehicles charged using solar power emit 96\% less mass of pollutants than all-electric vehicles using the grid (with four percent of pollutants remaining from brake and tire wear) [3]. In addition, photovoltaics emit no noise, chemical pollutants or radioactive substances during use, so they are not added nuisances to the surrounding community [17]. Although solar panels have some carbon dioxide emissions associated with their production, the panels become carbon neutral in two years, and have an average lifetime of over 20 years [3]. Reducing carbon emissions using solar power will help the nation reach proposed US federal plans to reduce the nation's 2005 carbon emission levels by $30 \%$ from the electric power sector by $2030[18,59]$.

\subsection{Benefits of SPCS}

Physically, SPCS are typically structures several feet tall with solar panels on slanted roofs and with an electric charging station underneath. One social value associated with SPCS is convenience since SPCS can be installed at many diverse locations such as work places, shopping centers, restaurants, rest stops along highways, gyms, parks, and more, allowing people to charge their vehicle while completing daily activities [21]. An infrastructure of many SPCS allows EV owners to charge their EV more frequently, which facilitates driving further before returning home. SPCS also provide shade for the charging vehicle. Shade significantly reduces the internal temperature of the vehicle and protects the car from sun damage, such as warping and cracked interiors [21]. A study in Oklahoma [21] found that internal temperatures of small cars dropped from 172 degrees Fahrenheit when in direct sunlight to 111 degrees Fahrenheit when under shade [53]. This lower internal temperature results in more comfortable conditions for drivers entering their car and reduces risk of heat stroke [21]. In addition, when asked how much survey respondents would like to park in shaded parking spaces on a scale of 1-9, 9 meaning "I would like it very much", the mean score was 6.40 with a standard deviation of 2.45 . This average score indicates that the majority of respondents are interested in shaded parking. Another social value of SPCS is shelter since the roof of SPCS protects the vehicle from rain, ice, and snow [21]. This can be beneficial especially in the Midwest of the United States where weather can be unpredictable, and hail and snow are more common.

SPCS can increase the number of green jobs with needs for installation, maintenance, and operation [22]. An estimated number of 4000-5000 jobs will be created per year with distributed 
photovoltaic power generation [17]. Solar powered charge stations also improve the green image of the establishment that installs the charging stations, and could count towards LEED certification [22]. In addition, SPCS would attract more customers to the establishment [1]. A study showed that 50\% of Americans believe it is "very important" that employers are environmentally responsible [1]. Also, that study found that $57 \%$ of consumers believe it is important to support products with environmental benefits and $51 \%$ will pay more for them, even during tough economic times [1].

SPCS could also serve as an educational tool, especially if installed at a school. The SPCS could raise awareness of solar power and electric vehicles, and could possibly encourage homeowners to install solar panels themselves [21].

Of the K-State survey respondents, $66 \%$ were in favor of installing solar powered charging stations for electric cars in campus parking lots. Table 3 shows the percentages for the reasons respondents favor SPCS.

Table 3. Reasons in favor of solar powered charging stations (SPCS) in K-State campus parking lots.

\begin{tabular}{cc}
\hline Reasons & Percentage \\
\hline It would be good for people with electric vehicles to charge their car & $86 \%$ \\
It would be good for air quality and reducing air pollution & $75 \%$ \\
It would encourage more electric vehicles & $65 \%$ \\
It would fit with the 2025 K-State Sustainability Plan & $64 \%$ \\
It would help the image of K-State & $60 \%$ \\
It would provide more shaded parking & $40 \%$ \\
\hline
\end{tabular}

As Table 3 shows, most people are in favor of SPCS because they believe it would help those with electric vehicles charge their car, and it would be good for air quality and reducing air pollution. Over half the respondents also believe SPCS would encourage more electric vehicles, would fit with the University's strategic vision plan, and would help the image of the University.

\subsection{Design and Price Aspects}

The ideal SPCS would be $27 \mathrm{~m}^{2}$ of solar panel area on an overhead structure with a power output of about 3-4 kW and a level 1 or level 2 electric charge station underneath. Level 1 charge stations are the slowest of three charge levels, with a power level of about $2 \mathrm{~kW}$. Level 1 is also the least expensive charge level, making it the most economical option. The slower level 1 charging rate should not be a concern for those parking for a significant time. For example, for a typical workday or school day employees or university students, faculty, and staff are parked for about eight hours, which is sufficient time to charge the car battery. In contrast, for customers who are parked on average for one hour, like a grocery shopper for example [40], level 2 charging is likely the best option for owners of BEVs [15]. Although this level of charging is slightly more expensive to install, the faster charging rate is more logical for the time spent parked.

A south-facing solar panel in Manhattan, Kansas with a DC to AC derate factor of 0.819 and 39.1 degree tilt, with an area sufficient to cover a SPCS of $27 \mathrm{~m}^{2}$, is estimated to produce an average of $16 \mathrm{kWh}$ per day and $5840 \mathrm{kWh}$ annually. The solar power produced is fed into the grid and electricity is drawn from the grid when an electric vehicle is charging. This design guarantees that an electric car can 
always be charged and that the generated solar power is always being utilized. SPCS provide many benefits for the installer and customers, but they ultimately are financial investments. Installing a $4 \mathrm{~kW}$ solar panel system at $\$ 4.00$ per watt costs about $\$ 16,000$ or $\$ 11,200$ with a federal tax credit of $30 \%$ of the net cost at installation; this is an estimate since solar panel costs vary depending on manufacturer, panel type, and installation costs.

The total costs for SPCS depend on the charging station hardware equipment, installation and maintenance costs, and cost of electricity [1]. Charging station hardware equipment for SPCS, such as the communications, charge level, and customer interface, can vary from $\$ 500-\$ 7000$ depending on the complexity of the system [1]. The $\$ 500$ equipment is the simplest equipment option where there is a cable and electric connection while the $\$ 7000$ equipment is the most complex option where there is a pre-built charging station that allows smart metering and collection of customer information [1]. Level 1 charge stations tend to be less expensive than level 2 charge stations. Installation and maintenance prices can range from about $\$ 165-\$ 400$ on average [1]. Using the estimated values, the SPCS may range from about $\$ 11,865-\$ 18,600$ per SPCS; but the station costs likely average closer to $\$ 18,600$ based on previous SPCS installments. When simply considering savings from generated solar power (using the average U.S electricity cost of $\$ 0.12$ per $\mathrm{kWh}$ ) [8] and excluding additional revenue for an entity, such as parking permits, the payback period for SPCS is estimated to be about 17 years for the lowest estimated cost and about 26.5 years for the highest estimated cost. Since electricity costs vary from one entity to another and with time of day, these estimated payback periods are also subject to change. Since solar panels produce power during peak hours when demand is greater, they have increased value where time of use (TOU) prices are used. Although the estimated payback periods of 17-26.5 years seem relatively long, other federal incentives or benefits, or partnerships could decrease the cost estimate of SPCS. In addition, SPCS increase a company's customer base because of its green image [22], which would increase the company's sales, and provide another location for advertisements [1]. Therefore, the total payback period for SPCS is likely shorter than the estimated range of 17-26.5 years.

\subsection{Financing SPCS}

There are multiple ways to finance the installation of SPCS including federal tax incentives or grants, partnerships with a utility or business, donations, or purchase power agreements. A power purchase agreement is where a private company pays for the installation and maintenance of the SPCS for an entity, and receives payments from that entity for the power and services received [23]. Once the contract expires, the university or entity can buy the solar charging station system at a reduced price or renew the contract [23]. Power purchase agreements are currently allowed in 22 US states, Washington D.C., and Puerto Rico, but banned by law in NC, GA, FL, IA, OK, KY and are unclear or unknown in the remaining states [23].

Table 4 shows the percentage of respondents who were in favor of certain financing options for SPCS. 
Table 4. Finance Options for Solar Powered Charging Stations.

\begin{tabular}{cc}
\hline Finance Option & Percentage \\
\hline Federal grant & $73 \%$ \\
Partnership with electric charging station company & $57 \%$ \\
Income from user permits & $55 \%$ \\
Power Purchase Agreement & $51 \%$ \\
Partnership with Westar Energy Utility & $51 \%$ \\
Donations to K-State Foundation & $50 \%$ \\
Tax incentives & $31 \%$ \\
University funds & $22 \%$ \\
\hline
\end{tabular}

The results in Table 4 suggest that respondents are open to many different finance options, which is a positive result since installers of SPCS may likely use several financial avenues to fund an installation. Also, the actual financing of SPCS that have been installed includes several of the options in Table 4. Goldin et al. have reviewed the financial aspects of several SPCS [3]. Federal grants have been received and used to help finance many of the early installations [3]. Electric charging station companies have been a partner in many installations [3,61,62]. Income from users of the charge stations is common; in some cases the charge is for parking; in other cases it is for the electricity; in other cases there is a fixed charge similar to a user permit $[3,61,63]$. For some installations, the SPCS are installed and financed by a power company $[46,47,64]$. Tax incentives have reduced the cost of the installation of SPCS [3]. Examples of SPCS financing include the Tesla Supercharger network which is financed by Tesla and provides free rapid charging to Tesla owners [30,41]. The sales of new Tesla vehicles provide the income to pay for the network. Similar to the Tesla Superchargers, in the Netherlands the Fastned network is being installed by a corporation that has many investors [63]. The investments and revenue from those who use the stations to charge their vehicles are financing the construction of the charging network [63]. In addition, Stanford University proposed a scenario of installing SPCS on campus and using a power purchase agreement to fund the purchase and installation of solar panels [24].

Another important aspect to consider for SPCS is the parking price structure. The three most common pricing structures that universities, businesses, utilities, and cities have used for charge stations include free charging, metered charging, or a flat rate. Since free parking is already provided at many businesses or around town, these entities often choose to provide free charging to encourage customers to use the stations and to have a competitive edge over other businesses [22]. Cities or companies that already have a pricing structure, that cannot financially support free charging, or that want to avoid scrutiny of customer preferential treatment often choose to provide metered pricing [22]. Metered parking is best when drivers are not parked for many hours and when level 2 charging is used. These hourly charge rates encourage vehicle turnover and prevent the exploitation of a charge station, Metered pricing must be reasonable to compete with other businesses [22].

Entities usually have flat parking rates when customers or employees are parked for many hours a day, multiple times a week. Level 1 charging is often the most logical charge level to use for these situations. Since level 1 charging takes several hours and the cars are often parked for about eight hours a day (typical workday), 250 days of the year, it is more reasonable for the user to pay a flat rate rather than pay an hourly price every day. This option is also more convenient for the driver since they do not 
have to move their car during the workday as they would with metered charging. The survey proposed two permit price structures for use of SPCS. One price structure option was for all drivers to pay the same price, but slightly higher than usual, for their parking permit, and all drivers have access to the SPCS. However, $77 \%$ preferred the staggered price structure instead, in which, drivers who park in open lots without using the SPCS have the least expensive permit, drivers who park under the SPCS for simply use of the shade and shelter have a slightly more expensive permit, and drivers who park under the SPCS to charge their car have the most expensive parking permits. The average amount survey participants chose to pay more for their annual permit to park in the shade was $\$ 25$. Since shade is typically a free commodity, the fact that these respondents are willing to pay extra for it indicates that consumers value this benefit.

\section{Electric Charge Station Infrastructure}

Consumers hesitate to purchase electric vehicles because of high costs, concerns of battery capacity, and lack of charge station infrastructure [26]. Consumers fear that the electric vehicle would need to be charged before they reached their destination or located a charging station, experiencing "range anxiety" [3]. With recent technological advancements, battery capacity and large costs are no longer major barriers to electric vehicle purchase; however, lack of charging station infrastructure continues to be a major concern $[3,26]$.

To provide perspective, as of May 2014, there are about 200,000 plug-in EVs sold in the US and 20,000 publicly available electric charging stations located throughout the nation [27]. As a result, there are about 10 electric cars per public charging station. Plug-in electric vehicles need to be charged every day or every other day. Thus, there is a need for a greater number of SPCS to satisfy the growing demand. In addition, several hours to charge an electric vehicle is a relatively large amount of time to allot in one's schedule; therefore, vehicle owners must be able to charge their car while completing other tasks or at home. More SPCS need to be available at work sites, shopping centers, restaurants, and other places where drivers spend time in addition to their homes.

Electric car charging cannot follow the same model as gas stations. Instead, electric car charging needs to be incorporated within existing parking lots so that drivers can multi-task and run errands, eat, or work as their vehicle is charging. Electric car charge stations need to be located along highways to facilitate drivers making long trips. Tesla Motors has started building Superchargers along major highways at places like restaurants and motels that allow drivers to eat or sleep while recharging their car before continuing their drive [30]. Charge stations can be built at restaurants and rest areas, which have restrooms, vending machines, and maps, and provide additional amenities such as wireless Internet connection for people to use their electronic devices and multi-task as their car charges. Infrastructure must also be developed in locations around town for those completing everyday tasks such as working, eating, buying groceries, or spending time at the gym or library. As the number of electric vehicle owners increases, places that lack charging stations could lose business.

With technological improvements, the time for electric cars to charge will decrease. However, more strategically placed solar powered electric charging stations are still needed to increase the locations that are available and decrease the ratio of electric cars to charging stations [5]. If there is greater car charging infrastructure, a positive feedback loop will be initiated and more drivers will purchase electric vehicles [5]. 
Currently, $1 \%$ of survey respondents own an electric vehicle, but $31 \%$ are more willing to invest in an electric vehicle if the university has sufficient charging infrastructure. If there happens to not be many electric cars in the area yet, installers of the SPCS could still feed solar power into the electrical grid, and customers or employees with any car could use the charging stations for shade and shelter [5].

NRG Energy Inc. has installed hundreds of eVgo charging stations in California, Washington DC, and Texas with plans for more charging station installations. Coulomb Technologies has installed over 4600 stations in Texas, Florida, New York, Michigan, and other US regions, and more stations in 13 other countries [31,32]. These companies and others have begun building the necessary electric car charging station infrastructure and have played a key role in the growth of electric vehicles. Thirty-one percent more electric vehicles have been purchased in the first five months of 2014 compared to the first five months of 2013 [27]. As the number of electric vehicles increase, the number of solar powered electric charging stations must increase to support the greater charge demand and to avoid overloading the grid [3]. If there is a $30 \%$ increase in plug-in hybrid electric vehicles, there may be a 1.5 time increase in peak load electricity consumption in a residential area [19,20]; SPCS can help meet this peak load.

For entities that decide to install SPCS, an aspect to consider is where to best locate them. In the survey, specific K-State parking lots and locations were proposed to respondents including west of old stadium/alumni center, the Federal National Bio and Agro-Defense Facility on campus, north of Call Hall, a location near the building they frequent most, the Bill Snyder Family Football Stadium, and a central location on campus.

Descriptions of the K-State locations with pros and cons were included in the survey questions and are used in Table 5; these can be applied to parking lots with similar characteristics at other universities, businesses, or entities. Respondents scored the proposed locations a number between 1 and 9 where 1 meant not a good location at all and 9 meant an excellent location.

When observing the results, it is evident that the location with the highest score was not a central location on campus, which may have been expected, but rather a large lot with many available parking spots that is located far from main buildings. Some survey respondents expressed concerns about SPCS reducing the number of available parking spots, making it more difficult to find a place to park; therefore, this large lot may have the highest score because it has open spaces available most of the day. In addition, the second highest scoring location is a new federal building planned to be built on campus. It is possible respondents favored this location because the future parking lot could be constructed with extra parking spots for SPCS. The federal building lot may also rank second because it would support the proposed new U.S. federal rule to reduce greenhouse gas emissions [18,59], which was mentioned in the survey question. The survey respondents' preferences and hesitations associated with SPCS installations indicate the concerns the majority of non-EV owners may feel with the construction of SPCS. These anxieties should be considered when designing an entities' SPCS business model. When looking specifically at the preferred SPCS locations of respondents who own electric cars or would like to own an electric car, the most favored locations were large lots with many available spots and multiple locations so there is a station near the building they most frequent. 
Table 5. Preferred Locations for SPCS.

\begin{tabular}{ccc}
\hline Location & $\begin{array}{c}\text { Mean } \\
\text { Score }\end{array}$ & $\begin{array}{c}\text { Standard } \\
\text { Deviation }\end{array}$ \\
\hline Large lot, often with available spots for parking, but quite far from main buildings & 5.48 & 2.57 \\
\hline $\begin{array}{c}\text { Federal building on campus. SPCS would mainly be for federal employees } \\
\text { but would support the new federal emissions rule * }\end{array}$ & 4.75 & 2.68 \\
\hline $\begin{array}{c}\text { A certain lot with a central location on campus, } \\
\text { but not many buildings relatively close to the lot }\end{array}$ & 4.62 & 2.49 \\
\hline Location near building respondent frequents most & 4.54 & 2.77 \\
\hline Football Stadium at far end of campus & 4.12 & 2.73 \\
\hline Central location on campus in general & 3.97 & 2.46 \\
\hline $\begin{array}{c}\text { * The proposed new US federal emissions rule involves reducing the nation's } 2005 \text { carbon emission levels by } \\
\text { 30\% from the electric power sector by 2030 [18,59]. }\end{array}$ & \\
\hline
\end{tabular}

The reduction of greenhouse gas emissions and the improvement of urban air quality can be accomplished through the electrification of transportation, increased SPCS infrastructure, and greater renewable energy generation. This can be achieved with present technology, but the transition is expected to benefit from continuing advances in solar energy, battery technology, and SPCS developments. Additional choices in electric vehicles and plug-in hybrid vehicles are expected as more individuals select these options. As the world moves forward with new emission guidelines, reducing their countries reliance on fossil fuels, and upholding other environmental policies, it is important countries continue building electric car charging infrastructure that incorporates solar power.

\section{Business Models}

A business model for SPCS describes the rationale associated with providing value in social, economic, and environmental contexts $[65,66]$. For commercial companies, a business model is a plan to generate revenue and make a profit from operations [65]. For SPCS, the social value of conveniently located SPCS, the environmental value of green solar energy, and the economic aspects are important parts of the business model to be addressed $[65,66]$. The payback period, the length of time required for the income associated with an investment to equal the capital invested, is often used to evaluate alternatives.

The survey results can be used to design business models for various situations in which SPCS may be viable to install, as well as identify parameters outside of which the installation of SPCS are not yet economically recommended. In addition, the survey results can indicate the opinions or hesitations the general public may have with aspects of SPCS installation and logistics. The preliminary models developed here include models for non-profit organizations (using universities as an example), industries like single businesses and shopping centers, utilities, public parking, and federal and state governments. Because of length of time and frequency, workplace charging has been given more attention. The U.S. Department of Energy has a popular Workplace Charge Challenge program with over 60 participating companies and organizations [56]. 


\subsection{University Non-Profit Organization Model Parameters}

Parking services at large non-profit organizations, such as universities, are often self-supported. The income acquired from the parking permits and citations is used to develop and maintain the university parking lots. The majority of university students, faculty, and staff park in open parking lot spaces, as the survey shows, in order to save money and park in more convenient locations. Installing solar powered charging stations in these lots can provide some of the benefits a parking garage provides, such as shade and protection from weather, but at a more convenient location and comparable price to parking garages. Although the amount of electric vehicle ownership at universities is still relatively low overall, the survey indicates that there is a growing interest in owning an electric vehicle and support for the installation of SPCS. The purchases of electric vehicles are expected to increase with the greater availability of electric car charging stations [5,41].

SPCS have been estimated to be about $\$ 11,865-\$ 18,600$ each. SPCS seem to be relatively expensive, but there are values associated with these stations in addition to power generation and charging such as shade, protection from rain, ice, and snow, the improved image of the university, and reduced carbon dioxide emissions that make the price seem more reasonable [21]. Student, staff, and faculty do not need to own an electric car to use the shade and shelter of the SPCS. When considering the value of these benefits, the charging stations have the potential to be successful.

When considering methods to finance SPCS, there are multiple options; one popular option many installers use is tax incentives. In order to qualify for certain renewable energy credits or tax incentives, the university may need to form partnerships with other companies [5]. Federal tax incentives include the Solar Investment Tax Credit, which provides a 30\% tax credit for solar systems, valid through 2016 [33]; the Renewable Energy Property Tax Exemption, which exempts renewable energy equipment from property taxes [60]; the Electric Vehicle (EV) Infrastructure tax credit, which is a 30\% credit of the charge station cost with a max of $\$ 1000$ for consumers and $\$ 30,000$ for businesses [34]; and Business Energy Investment Tax Credit (ITC) which equals 30\% of expenditures [34]. The Database of State Incentives for Renewables and Efficiency is a helpful database that lists incentives for all US states, and should be further perused for updated tax incentives [35].

A partnership with an electric charging station company may also be a viable option for financing SPCS for a non-profit organization. For example, ChargePoint, an electric charging station company, donated a charging station to K-State, which charges an hourly rate for use of the station. The company benefits from receiving $10 \%$ of the monthly revenue generated from use of the station and from customers subscribing to the ChargePoint infrastructure [36]. On the other hand, K-State benefits from receiving the charging station for free and $90 \%$ of the income generated from station use, while improving their image. A similar scenario could be followed at other universities.

Another possible finance option is a partnership with a business. In this case, the business purchases the SPCS and pays for the installation, but in return receives free advertising on the campus charge station for a certain number of years. Spending about $\$ 11,865-18,600$ per station in return for multiple years of free advertising on a college campus can be an attractive deal for businesses. This partnership allows the university to spend no money on the charge stations, but still improve their image, generate revenue from station use, and reduce their electricity bill with generated solar power. In addition, it allows businesses to reach a large advertising audience for multiple years. The university could request 
Tesla Motors, Nissan, or Chevrolet to donate a SPCS for example and in exchange the car company would receive free advertising. Partnerships with businesses or electric charging station companies (or both) are win-win situations.

Most universities sell annual parking permits for students, faculty, and staff to park on campus. University permit parking prices vary depending on classification as student, staff, or faculty and the location of the parking for faculty and staff. For example, K-State students pay $\$ 170$ for an open parking lot spot while K-State faculty and staff pay $\$ 150-\$ 190$ for an open parking lot spot, $\$ 410$ for a preferred garage spot, and $\$ 610$ for a reserved garage spot [37]. The addition of solar powered charging stations on campus will alter the pricing structure for university parking. Based on survey results, the best pricing structure is staggered pricing where it is least expensive to park in open lots without using the SPCS, slightly more expensive to park under the SPCS to simply use the shade and shelter, and most expensive to park under the SPCS to charge an electric vehicle. The average amount survey participants chose to pay to park in the shade in addition to their existing parking permit price was $\$ 25$. Therefore, for the new pricing structure the shaded parking spot prices would be $\$ 25$ more expensive than the average spots, and the parking permit prices for using the charging station would be about $\$ 300$ more expensive. The additional $\$ 300$ is actually a reasonable pricing amount because it includes not only shade and shelter (amenities which parking garages provide), but also allows unlimited charging for electric cars. When comparing the new permit price to the K-State case, it is evident the SPCS charging permit is actually between the $\$ 410$ and $\$ 610 \mathrm{~K}$-State garage permit prices. Thus, the additional $\$ 300$ for unlimited annual charging appears to be a reasonable price that provides several benefits and is comparable to current university permit prices.

As already mentioned, the estimated payback period for SPCS is slightly below or equivalent to the typical 25-year warranty for solar panels [38]. It is important to remember that the payback period would decrease with the addition of tax incentives, partnerships, and user parking permits, which 55\% of respondents were in favor of. Also, the payback period could decrease further if the university or non-profit entity slightly increases the permit prices annually.

Besides price and payback period, another logistical aspect to consider regarding SPCS is location. According to the survey results, the majority of respondents prefer SPCS to be placed in parking lots that are typically located far from main campus buildings but have an abundant amount of parking spaces. Most respondents seemed to value available parking spots higher than conveniently located parking. Respondents who own or would like to own an electric car preferred locations for SPCS in large lots with many available spots or in multiple locations. The future plans for the university should also be considered when planning locations for SPCS. For example in the K-State case, the University has a 2025 Master Plan that plans to move surface parking from around campus locations to the Bill Snyder Family Football Stadium parking lots at the edge of campus where shuttles will take people to campus [39]. Therefore, in anticipation of this future plan of campus parking relocation, it is logical for K-State to build some SPCS at the Bill Snyder Stadium lots.

There is also value for other universities to build SPCS at their football stadium parking. Often many alumni will attend university football games and may travel many miles, especially in the Midwest of the US, to attend the games. Thus, it would be convenient to have a charge station infrastructure to allow commuters with electric vehicles to charge their car during the game, especially if the commuter could not return home on the remaining battery charge otherwise. Tailgating and football games often last for 
about $6 \mathrm{~h}$ or more collectively, which is sufficient time to charge many of the car batteries. Another benefit includes allowing alumni or others to use the charge stations for social reasons as they tailgate before a football game. The SPCS would provide shade and shelter for the tailgating party. In addition, level 1 SPCS would allow tailgaters to plug in their television, grills, or other electronics. The SPCS would be an additional tailgate amenity, making alumni's football game experience more enjoyable. The SPCS in the football parking lots would demonstrate to alumni and other game-goers the sustainability progress the university is making and thus further improve its image. In addition, the SPCS could generate more revenue for the university if tailgaters or electric vehicle owners were charged for use of the station. Extra income from tailgaters would help pay for the cost of the SPCS installation and maintenance, further reducing the payback period.

\subsection{Industry}

A number of employers now have workplace charging for their employees and customers [56]. Many benefits associated with SPCS related specifically to businesses include increased clientele base, credit towards LEED certification, shelter, convenience, and a car charging service for customers and employees [5,22]. As Table 3 demonstrates, customers value that SPCS encourage more EV purchases, improve air quality and reduce air pollution, improve the image of the establishment, and provide more shaded parking.

Customers typically spend an average of one hour at a store [40]; therefore, SPCS at these businesses should be capable of both level 1 and level 2 charging. Level 1 charging is needed because some electric cars only have capacity for this charge level, some employees or customers may be parked for a significant time in the lot, and because level 1 is the best level to use with solar power. Level 2 charging is needed because it will allow customers to almost or completely charge their vehicle in the time they are shopping at the store [15]. Since a SPCS generates about $4 \mathrm{~kW}$, solar power cannot provide all the electricity required for a $7 \mathrm{~kW}$ level 2 charge station. Thus, the SPCS must be able to access electricity from the grid when necessary.

Since the average industry electricity cost is less than the average residential electricity cost (although exact electricity costs vary by region and negotiated agreements) [8], the estimated payback periods may be larger for industry compared to residential. Despite the larger estimated payback period, businesses may continue to invest in SPCS due to the associated benefits such as improved green image, shade, convenience, and wider clientele base $[5,22]$. In other cases, charge stations are installed without solar panels.

Due to the relatively high initial cost for SPCS, the economics of industrial-based SPCS do not seem particularly attractive at this point. However, some businesses are proving this perception incorrect. For example, Tesla Motors is working to install electric vehicle Superchargers across the US and other countries as well. Superchargers are $120 \mathrm{~kW}$ chargers that have the capability of charging $50 \%$ of a Tesla car battery in $20 \mathrm{~min}$ [30]. Each station also has a half-megawatt-hour battery pack [30]. Tesla is also working to have every charge station have grid storage capabilities and solar power [41]. There are already 102 stations in North America with complete East and West coast coverage and coast-to-coast travel in the US, as well as 44 stations and nine stations located in Europe and Asia, respectively [30]. The chargers are located near other amenities like restaurants, shopping centers, and cafes, allowing users to complete another task while their car is recharging [30]. Each Supercharger costs $\$ 150,000$ to 
install, but use of the station is free for Tesla car owners [41]. The solar panels, covering six parking spaces, add an additional $\$ 150,000$ to installation costs [41]. These high upfront costs may seem prohibitive, but Tesla Motors' business model is faring well. The provision of free, abundant, quick charge stations is reducing customers' anxieties, like range and prevalence of stations, and encouraging customers to purchase Tesla's electric vehicles [41]. Tesla is also able to use the half-megawatt-hour battery pack to avoid utility "demand charge" fees that occur if a Model S Tesla plugs into the grid, causing high increases in electricity use [41]. The battery pack may be used in the future for grid services, like grid stabilization, which would generate additional revenue for the company [41]. Superchargers help support Tesla's business model and play a large role in increasing the number of electric vehicle purchases. Despite the high initial costs for the Supercharger infrastructure, Tesla is demonstrating SPCS to be a feasible investment.

\subsubsection{Single Business}

The typical payback period for businesses to invest in an item or technology is 5-7 years [55]. The larger estimated payback period for SPCS is significantly greater. One option for a business to install SPCS in an economically viable way is to engage in a partnership with another entity to share the cost.

NRG eVgo has partnered with Walgreens and is installing 120 electric car charge stations across areas in Texas [42]. Walgreens is serving as the host site for the stations while NRG eVgo pays for the installation and maintenance, and offers subscription plans of monthly flat rates for customers [42]. Walgreens is able to benefit from having the electric car charging stations by increasing their customer base and improving their image without paying for the charge stations. Establishing partnerships with another entity reduces the initial cost associated with SPCS.

According to the present survey, 57\% of respondents were in favor of the business partnership finance option. The host business and SPCS owners both benefit from this partnership. The host company receives the benefits of SPCS, such as improved image, greater customer base, and shaded parking for free while the partnering company is able to market their name, improve their own image, and increase their profits from customers' charging. In this case, the two partners usually determine the pay structure for the stations, which can be free charging, a membership flat fee, or an hourly rate. It is best to model the new pricing structure based on the current parking price structure at the host business; this provides consistency and reduces customer accusations of preferential treatment [22] (pp. 28-31). If parking at the host business previously was free, it should continue to be free for customers to use the charge stations in order to compete with other businesses hosting charge stations [22] (pp. 28-31). If parking at the host business previously cost money, the business should use the same pricing structure (hourly rate or flat fee) for the SPCS fees, although the prices may be higher.

Another viable form of partnering for the installation and use of SPCS at a reduced cost, if allowed in that state, is power purchase agreements (PPA), which 51\% of survey respondents favor. PPA reduce the initial investment and maintenance cost of SPCS for host businesses since the partnering business owns the stations and thus funds the project [23]. The host business would pay a contracted fee for the SPCS to the partnering station owner for a certain number of years, usually around 25 years, until the contract ends. Once the contract ends, the host business could purchase the SPCS from the owners at a reduced cost or renew the contract. This agreement allows host businesses to avoid the initial upfront 
cost of the SPCS installations, and allows the partnering business to benefit from the financial incentives and market their company name [24]. Partnerships can allow multiple entities to benefit from the installation of SPCS.

\subsubsection{Shopping Center}

A shopping center can have 10 or more businesses in a plaza with shared parking spaces; if the 10 businesses share the cost of the SPCS, this has a benefit similar to sharing the cost of the parking area. SPCS would improve the plaza's image and draw more customers to the entire plaza, benefiting all the businesses.

Parking offered in shopping centers is usually free; therefore, the SPCS should also be a free amenity. In order to pay for the SPCS installation and maintenance, and the electricity consumed that is not already offset by the generated solar power, the businesses could use store income [5]. Another possible option is for the government, with the community's approval, to engage in an agreement with several shopping centers around town, allocating a percentage of sales tax to cover SPCS installation and maintenance costs. Using sales tax allows customers to indirectly pay for the SPCS as they purchase food or items at the shopping center stores. Those who do not have EVs can benefit from shaded parking provided by the SPCS.

If not all the businesses in the shopping center are interested in financing SPCS, the businesses who are interested could still split the cost or engage in a partnership or PPA with another entity. The participating businesses could require customers to use a loyalty card or a code, available only at their stores, to use at the SPCS; this way, the other businesses not paying for the SPCS do not receive the benefits of improved image or increased clientele for free [22].

Since the solar panels on SPCS are designed to feed electricity straight into the grid, it does not matter what time of day electric vehicle owners charge their car. Therefore, it is not an issue that many customers typically shop at shopping centers in early to late evening when there is little or no solar energy generated; the SPCS will be just as beneficial and will provide the needed infrastructure.

\subsection{Utilities}

Utilities often deal with a reputation of being anti-environment due to their continued fossil fuel use. Utilities can improve their image with the installation of SPCS. Most customers would be more inclined to support a utility if it is advancing environmental initiatives, like electric vehicles and SPCS [1]. Regulated utilities have the obligation to provide power at a profitable rate and to provide power for electric vehicles at public locations. SPCS could generate more revenue for utilities while providing necessary charging infrastructure, and counting toward the Renewable Energy Portfolio if present in that US state. The Renewable Energy Portfolio Standard (RPS) is a mandate designed to increase electricity generation from renewable sources like solar, wind, and biomass [43]. There is no national RPS for the US, but 31 states currently have an RPS and seven other states have renewable or alternative energy goals [44]. This standard has been effective in encouraging electricity producers to increase the percentage of their electricity generation on renewable sources rather than fossil fuels [43]. In addition, SPCS would help utilities meet the proposed new US federal rule to reduce the nation's 2005 carbon emission levels by $30 \%$ from the electric power sector by 2030 [18,59]. Another benefit is that the utility 
could sell electricity when the utility's SPCS are being used in the evening or at night (when there is little to no solar power generated).

Utilities have the opportunity to partner with businesses or universities, supplying SPCS for an entity that serves as the stations' host. According to the survey, $51 \%$ of respondents are in favor of a partnership with a utility to fund SPCS. Austin Energy, located in Texas and the nation's eighth largest public owned utility, has engaged in partnerships with Wal-Mart, Sam's Club, H-E-B, and Denny's to install SPCS at locations around Austin $[45,46]$. By January 2013, Austin Energy's electric car charging sessions collectively helped save 7363 gallons of gasoline, and the electric charging, which is totally powered by renewable energy, helped prevent 1391 pounds of greenhouse gases from being emitted into the atmosphere [47]. Other utilities can also have a positive impact on the environment and market this fact with the installation of SPCS. In addition, utilities can use electric vehicle batteries as grid stabilizers, similar to Tesla's Supercharger battery, which is helpful for the utility's operations [48]. Benefits for SPCS host businesses include increased clientele base, improved image, and recognition for the support of renewable energy and encouragement for more electric vehicle purchases [22]. It is still being debated in some states whether utilities can own and operate charging stations, and whether utilities should be the only ones to own public charging stations [49]. Most states have yet to rule on this issue, but those who have, such as Washington and Oregon, have permitted utilities to own public stations [49].

In order to pay for electricity consumed, Austin Energy customers engage in a six-month subscription for unlimited charging within the network or pay an hourly fee for use of the SPCS [46]. For other utilities, subscriptions, hourly priced charging, or a price per $\mathrm{kWh}$ of electricity used are also viable finance methods for level 1 and level 2 SPCS. The SPCS charge level would depend on the utility's partner and customer needs.

Unlike other entities, utilities have the ability to charge a certain price per kWh of electricity used if sanctioned by the utility regulatory agency that approves prices. For example, if approved, the utility agency could charge $\$ 0.15$ per $\mathrm{kWh}$ of electricity delivered at a charge station, which would be $\$ 0.05$ per mile for an electrical vehicle that averages 3 miles per $\mathrm{kWh}$. With this charging structure, the payback period for SPCS is 13.5-21 years. This $\$ 0.15$ per $\mathrm{kWh}$ charge rate is a reasonable price for utilities that results in a profit, but it is slightly high for the consumer. However, the idea for these higher priced SPCS is to have these stations available in many locations so customers can use them if they need to recharge. With an appropriately regulated price per $\mathrm{kWh}$ charge rate, it is profitable for the utility to sell power from the grid at the charge station.

Another finance option for these utility-owned SPCS is metered charging where customers pay an hourly rate for use of the station. This allows for vehicle turnover and encourages customers to be more conscious of their electricity consumption $[25,58]$. To streamline the payment process, customers could simply enter their utility account information into the station and add the hourly charging fee to their utility bill [22].

Subscriptions are another option that ensure the utility a set amount of revenue each month and allow the customers to charge their vehicle however often they want that month.

Charging a fee to use a charging station located at host businesses with general free parking risks low use of the station due to the competition of free charging from other entities [22]. Customers would likely not be pleased to pay to park and charge their vehicle, when parking is usually free, and might go elsewhere to charge their vehicle. For example, survey respondents were asked how much they would 
be willing to spend for shaded parking, which is usually a free commodity, and 33\% were not willing to spend any money. Thus, customers may choose to go to free charge station parking locations. Therefore, it would be in the utility's and host business's best interests to provide free charging if free parking is already offered. The electricity provided at the charge stations can be free to the EV owner, but paid for by the business associated with the parking lot. Time limits could be placed on the charging to encourage turnover and prevent exploitation of the free charging. In order to ensure that only customers use the charge stations, businesses could require customers to use a loyalty card or code, available only at their store [22]. Another finance option includes charging businesses to place advertisements on the charging stations and using this additional revenue to help cover free charging costs. There are several finance options that utility-owned SPCS could employ. A partnership with a utility and the businesses they serve can be an effective option for increasing the SPCS infrastructure.

\subsection{Public Parking Model}

In cities, particularly in downtown areas, businesses often do not own parking lots, but rather the city does. Public parking is provided along streets and in lots, where there is free or metered parking, and in parking garages, where there is often an hourly rate. Parking availability is viewed as an incentive for downtown investment opportunities [50]. Independent business owners in these urban areas believe that accommodating vehicle users allows the businesses to compete with suburban shopping centers [50]. Customers of these businesses are from immediate and surrounding communities, and often travel downtown for errands, dining, or entertainment purposes. The local economy is improved when other city dwellers also travel to the city and spend money. However, electric vehicle owners with significant commutes may be hesitant to travel the long distance to the city if charge stations are not provided. The commuter may be unable to return home without charging their car battery beforehand. Therefore, it is wise for cities to install SPCS for public parking to encourage economic activity from these commuters as well as from other electric vehicle owners and environmentalists.

In areas with free public parking, which are often less convenient or less frequented places, free charging for SPCS should be provided. Free charging will encourage electric vehicle owners to travel to this city or area over another, and will entice them to shop at local businesses. Charging for SPCS spots adjacent to free spots, conversely, could discourage electric vehicle owners from using the stations and may cause them to charge elsewhere.

For parking spots with metered parking, SPCS should be provided with hourly rate charging. Charging an hourly rate will encourage more vehicle turnover, allowing more drivers to use the well-located SPCS spaces.

Both level 1 and level 2 charging options should be provided. Level 1 should be provided since some electric vehicles can only handle this level charging and some customers spend the majority of their day in town. Level 2 should also be provided since some customers only stay in the city for an hour or two and thus need a faster charging rate. Level 2 charging should also be used for metered parking since drivers will be parked in these spots for shorter times and will need a faster charging rate.

Cities can use a portion of sales tax to help pay for the installation, maintenance, and electricity usage of the SPCS as long as the community and government approves. Customers who are using the SPCS are purchasing items at the local businesses while parked, so the customers would be indirectly paying 
for the charge stations with sales tax. In addition, since commuters or tourists must pay sales tax as well, using this tax to fund SPCS seems logical.

Other options for financing SPCS include federal tax incentives, federal grants, or a partnership with a utility or company. For example, the city of Saint Paul, Minnesota partnered with the utility Xcel Energy and installed two SPCS. The stations were paid for partly by Xcel Energy and the City of St. Paul, and primarily by the US Department of Energy federal stimulus grant [51]. This city and utility partnership has worked well for St. Paul and these entities are continuing to work with businesses and non-profit entities to develop electric car charging infrastructure in Minnesota [51].

SPCS have an estimated 17-26.5 year payback period when simply considering revenue received from generated solar power (although this varies by utility and region). This payback period decreases, however, when factoring in federal incentives, grants, or partnerships the city has formed. In addition, revenue from sales tax and hourly charge rates for charging, if implemented by the city, can also decrease the payback period further. To further decrease the payback period, the revenue rate for SPCS can also be increased annually. Cities may still choose to invest in SPCS no matter the payback period because of the benefits associated with them such as infrastructure for EVs, shade, convenience, and improved image $[5,22]$.

\subsection{Federal and State Government Model}

Created under the Obama administration, a new federal plan has been proposed that calls for the reduction of $30 \%$ of the US's 2005 carbon emissions from the electric power sector by $2030[18,59]$. The US federal and state governments have the opportunity to lead the nation by example and work towards achieving this plan through the installation of SPCS in federal and state employee parking lots. Other country governments also have the potential to lead by example by integrating SPCS throughout their government's existing physical infrastructure.

Since employees typically work $8 \mathrm{~h}$ days, level 1 charging (the less expensive installation option) is sufficient for the charging infrastructure. Use of the charge station should be free and can be considered an employee benefit. US federal employees can currently apply for the Transit Benefit Program, an employer provided benefit that encourages employees to use mass transit for their work commute by

providing a monthly stipend that covers commute costs [52]. Mass transit is encouraged because it decreases emissions and the nation's reliance on fossil fuels. Providing free SPCS charging is equivalent to providing a mass transit stipend. Free charging will improve the image of the federal agency, support the proposed new US federal plan or other country's plan to reduce emissions, and encourage purchases of electric vehicles. Therefore, federal and state government agencies should install SPCS in employee parking lots and provide free charging as an employee benefit.

\section{Conclusions}

In order to decrease carbon emissions, electric power must be less dependent on fossil fuels and transportation must be electric. Due to electric vehicles' current high purchase costs and high costs of battery capacity, the infrastructure for charging stations must be increased to encourage more EV purchases. A significant SPCS infrastructure generates electricity for the grid and provides locations for public charging. In addition, the charging infrastructure must be integrated with the existing physical 
infrastructure, such as shopping centers and work places, to allow drivers to charge their vehicle while completing other tasks. Non-profit organizations, businesses, utilities, cities, the government, and other entities have the ability to facilitate this transition to an electric charge station infrastructure. There are key aspects these or similar entities should consider when designing their business models. One includes determining the best fit SPCS charging levels (level 1 or 2 or 3 ) for the consumers, which depend on the amount of time parked at the facility. Level 1 charging should be provided for vehicles parked for a full work day or about eight hours or more. Level 2 charging should be provided for vehicles parked about 1-2 h. Also, several financial avenues should be pursued to reduce the initial cost of the SPCS. The most widely used options include federal and state tax incentives, or a partnership with another business or charging company. The pricing for use of the SPCS largely depends on their current pricing structure for parking. Entities with free parking should primarily provide free charging, whereas those with metered parking should charge an hourly rate. Maintaining a similar price structure provides consistency.

Implementing SPCS into an entity's parking provide benefits such as improved image, increased clientele base, credit towards LEED certification, as well as convenience and shade for customers [22]. In addition, benefits of constructing SPCS extend beyond the entity and associated consumers; it provides a greater charging infrastructure for electric vehicles and helps shift the nation from a focus on fossil fuels to alternative fuel sources.

\section{Acknowledgments}

Thank you to the National Science Foundation for partially funding this research with the REU EEC-1166549 grant and thank you to Black and Veatch for their funding as well.

\section{Author Contributions}

Jessica Robinson: The main author for this publication who wrote the survey questions, conducted the survey, recorded and analyzed the responses, conducted the literature review, made calculations such as payback period, and wrote the manuscript.

Gary Brase: Gary Brase assisted with the Institutional Review Board Process, editing the survey questions, and with the survey process. He advised ways to word survey questions and ways to distribute the survey. He also assisted with editing the manuscript and added a paragraph when necessary.

Wendy Griswold: Wendy Griswold assisted with the Institutional Review Board process, editing the survey questions, and editing the manuscript.

Chad Jackson: Discussed and provided guidance for business models, and edited the manuscript.

Larry Erickson: Larry Erickson served as a research mentor to Jessica Robinson. He assisted with the planning process for the project, the Institutional Review Board, editing the survey and manuscript, and the survey process. He helped distribute the survey and the survey prize gift card. He added a paragraph when necessary to the manuscript and helped with some of the calculations. He also provided guidance and advice during the duration of the project.

\section{Appendix}

Survey Questions 
Section 1:

1. Are you a student, faculty or staff?
a. Student-14\%
b. Faculty-27\%
c. Staff-61\%

2. What is your age?
a. $18-22-10 \%$
b. $23-30-12 \%$
c. $31-40-17 \%$
d. $41-50-19 \%$
e. $51-60-\mathbf{3 1 \%}$
f. $61-70-9 \%$
g. 71 or more $-\mathbf{1 \%}$

3. How do you get to campus most frequently?
a. Walk-10\%
b. Bike-2\%
c. Drive $-83 \%$
d. Carpool-4\%
e. Public transportation- $\mathbf{0} \%$
f. Other-1\%

4. How many miles do you travel one way to get to campus?
a. $0-1$ miles $-\mathbf{1 3} \%$
b. $2-5$ miles $-\mathbf{4 4 \%}$
c. $6-10$ miles $-\mathbf{1 5 \%}$
d. 11-20 miles-10\%
e. 21-30 miles-7\%
f. $31-40$ miles $-\mathbf{5 \%}$
g. 41-50 miles-2\%
h. 51-60 miles-2\%
i. 61 miles or more-2\%

5. Do you own or have use of a car?
a. Yes-100\%
b. $\mathrm{No}-\mathbf{0} \%$

6. Do you have an electric car?
a. Yes-1\%
b. $\mathrm{No}-99 \%$ 
7. What type of electric car do you drive?

a. All electric plug-in- $\mathbf{0 \%}$

b. Plug-in vehicle that also uses gasoline- $\mathbf{2 5 \%}$

c. Gasoline vehicle that uses some battery, but is not a plug-in vehicle- $\mathbf{7 5 \%}$

8. Do you park a vehicle on campus or plan to in the next 9 months?
a. Yes-93\%
b. $\mathrm{No}-\mathbf{7 \%}$

9. Do you typically park a car or motorcycle on campus?
a. $\mathrm{Car}-99 \%$
b. Motorcycle-1\%

10 What type of permit do you have?
a. A permit to park in open parking lots $-\mathbf{7 8 \%}$
b. A permit to park in a reserved space in an open lot- $\mathbf{4 \%}$
c. A Reserved permit to park in the garage- $\mathbf{4 \%}$
d. A Preferred permit to park in the garage $-\mathbf{8 \%}$
e. I do not have a permit- $6 \%$

11 Please help us understand why you park in the garage. You may select all answers that apply to you.
a. The garage is a convenient location for me to park $-\mathbf{8 6 \%}$
b. The price seems reasonable-23\%
c. I value the ability to park in the shade $-\mathbf{5 7 \%}$
d. I value the shelter from rain, ice, and snow- $-77 \%$
e. I want the protection for my car, so it stays looking nice- $\mathbf{3 1 \%}$
f. I want the interior temperature of my car to not get too hot or too cold $-\mathbf{3 8 \%}$
g. I want to help pay for the garage- $\mathbf{1 \%}$
h. It is easier to find an open parking space in the garage $-\mathbf{4 7 \%}$
i. Other-22\%

12 Why did you decide to not pay the additional cost to park in the garage? You may select all answers that apply to you.
a. The garage is not a convenient location for me- $-\mathbf{6 5 \%}$
b. The price does not seem reasonable- $\mathbf{4 8 \%}$
c. I don't care much about the ability to park in the shade- $\mathbf{1 4 \%}$
d. I don't care much about shelter from rain, ice, and snow- $\mathbf{1 1 \%}$
e. There is congestion entering and leaving at some times of the day- $\mathbf{2 6 \%}$
f. I don't care much about the interior temperature of my car getting too hot or too cold- $\mathbf{1 2 \%}$
g. It is not my responsibility to help pay for the garage- $\mathbf{- 1 2 \%}$
h. It is just as easy to park elsewhere as it is to park in the garage- $\mathbf{2 9 \%}$
i. Other-11\% 
13 In general, which do you value more?

a. Parking close to my destination, but having a more expensive permit $-\mathbf{5 0 \%}$

b. Parking farther from my destination, but having a less expensive permit $-\mathbf{5 0} \%$

Section 2:

14 Independent of the electric car charging aspect, how much would you like to park in shaded parking spaces, rather than spaces exposed directly to the sun, rain, and snow? (Scale of 1 to 9 where $1=$ I would not like to at all, $9=$ I would like it very much)

Mean $=6.40$ Standard deviation $=\mathbf{2 . 4 5}$

15 Think about how much you currently pay for a campus parking permit (or how much you would pay once you get one). How much more would you be willing to spend annually for shaded parking? (Scale of $\$ 0$ to $\$ 200$ )

[To provide perspective for this question, several K-State parking permit prices are listed: annual parking lot permits for faculty and staff range from $\$ 150-\$ 190$, student parking is $\$ 170$, garage preferred parking is $\$ 410$, and garage reserved parking is $\$ 610$.]

Mean $=\$ 25.52$ Standard deviation $=\mathbf{3 9 . 3 3}$

16 Suppose you have an electric vehicle. You can reduce your cost to travel to and from campus (compared to a gasoline powered vehicle) by charging your vehicle on campus and at home. Would you like to be able to do this?

a. Yes- $64 \%$

b. No-36\%

If shaded electric charging stations were added to the parking areas of the university it would cost some money to build. There are two different ways that these costs could be put into the parking permits.

17 Which parking permit system would you prefer?

a. Parking permit prices vary depending on where the driver is allowed to park. People could pay the same amount as now, but have fewer parking spots to choose from. Other people would pay more for the ability to park in shaded spots or to use the solar electric charging stations. $-\mathbf{7 7 \%}$

b. Everyone pays the same parking permit price, which is a little bit more, and everyone can park in the shaded solar electric charging spaces and charge their car if they wish. $-\mathbf{2 3 \%}$

18 Which parking permit system do you think is most fair?

a. Parking permit prices vary depending on where the driver is allowed to park. People could pay the same amount as now, but have fewer parking spots to choose from. Other people would pay more for the ability to park in shaded spots or to use the solar electric charging stations. $-\mathbf{7 6 \%}$

b. Everyone pays the same parking permit price, which is a little bit more, and everyone can park in the shaded solar electric charging spaces and charge their car if they wish.- $\mathbf{2 4 \%}$ 
19 What is your general feeling or opinion towards solar energy? (Scale of 1 to 9 where $1=$ very negative opinion, $9=$ very positive opinion)

\section{Mean $=6.48$ Standard deviation $=2.39$}

20 Are you in favor of K-State installing some solar powered charging stations for electric cars in parking $\operatorname{lot}(\mathrm{s})$ ?
a. Yes- $66 \%$
b. No-34\%

21 Please mark all of the reasons why you favor having solar powered charging stations in K-State parking lots:
a. It would help the image of K-state- $\mathbf{6 0 \%}$
b. It would be good for people who need to charge their electric vehicles $-\mathbf{8 5 \%}$
c. It would fit with the $2025 \mathrm{~K}$-State Sustainability Plan-64\%
d. It would be good for air quality/reducing pollution- $\mathbf{7 5 \%}$
e. It would encourage more electric vehicles $-\mathbf{6 5 \%}$
f. It would provide more shaded parking $-\mathbf{4 0 \%}$
g. Other-6\%

22 Please mark all of the reasons why you are not in favor of having solar powered charging stations in K-State parking lots:
a. Presently the demand for charging stations is small $-\mathbf{7 8 \%}$
b. It would make parking more expensive- $\mathbf{- 7 8 \%}$
c. It would be a waste of money and time $-\mathbf{5 0 \%}$
d. It would be visually distracting- $\mathbf{- 1 2 \%}$
e. Other-21\%

23 Parking spots with solar powered electrical charging stations are shaded. How much would you like to park at and use a shaded solar powered charging station while at the university? (Scale of 1 to 9 where 1 = I would not like it at all, $9=$ I would like it very much)

Mean $=$ 3.91 Standard deviation $=\mathbf{2} .77$

24 Would you like to own an electric vehicle?
a. Yes- $\mathbf{4 0 \%}$
b. No- $60 \%$

25 Would you be more willing to invest in an electric vehicle if K-State had sufficient infrastructure for charging stations?
a. Yes-31\%
b. $\mathrm{No}-69 \%$

26 Do you think installing solar powered charging stations on campus will encourage more people to purchase an electric vehicle?
a. Yes- $\mathbf{4 0 \%}$ 
b. No- $-60 \%$

27 How should the solar powered charging stations be paid for? Select as many as you think apply. University funds

a. Federal grant-22\%

b. Donations to K-State Foundation-73\%

c. Income from user permits- $\mathbf{5 0 \%}$

d. Power purchase agreement. [A private company pays for the installation and maintenance of the system, and sells electricity to the university at a specified rate. Once the contract expires, the university can buy the solar charging station system or renew the contract.] $-\mathbf{5 4 \%}$

e. Partnership with Westar Energy utility-51\%

f. Partnership with electric charging station company- $\mathbf{5 8 \%}$

g. Tax incentives-31\%

Section 3:

If Kansas State University were to install solar powered charging stations, there are several different possible locations. Each location has advantages and disadvantages. For each of the following possible locations, please rate how good of a location it would be for installing solar powered charging stations. There are also multiple ways to fund the installation of shaded solar powered charging station parking. For the following questions, please indicate which payment methods you think are best. (Scale of 1 to 9 where $1=$ Not at all a good location, $9=$ an excellent location)

28 Bill Snyder Family Football Stadium parking lot. These parking spots are far from the center of campus, but could be used for shade while tailgating before football games. Do you consider this a good location for some solar powered charging stations?

Mean $=4.14$ Standard deviation $=\mathbf{2 . 7 4}$

29 A central location on campus. These parking spots are convenient to many buildings, but there are limited spaces and they are rarely open to park in.

Mean $=$ 3.98 Standard deviation $=\mathbf{2 . 4 6}$

30 Multiple locations, so there is one near the building you frequent most. This would involve more expense because of the multiple locations, but the location would be most convenient.

Mean $=4.93$ Standard deviation $=2.77$

31 West of the old stadium/alumni center. This lot is large and often has many available spots for parking, but the lot is quite far from the destinations of many students, staff, and faculty.

Mean $=$ 5.48 Standard deviation $=\mathbf{2 . 5 6}$

32 North of Call Hall. This has a central location on campus, but there are not main buildings relatively close to the lot.

Mean $=4.62$ Standard deviation $=\mathbf{2 . 4 8}$ 
33 K-State will be the location of a new federal building for the National Bio and Agro-Defense Facility. Mainly federal employees will work in this building, but solar powered charging stations here would support Obama's new plan to reduce the nation's carbon emissions from electricity $30 \%$ below 2005 levels by 2030 .

\section{Mean $=4.74$ Standard deviation $=\mathbf{2 . 6 8}$}

34 What is your opinion on the environmental sustainability of K-state?

(Scale of 1 to 9 where $1=$ A lot of need for improvement, $5=$ some need for improvement, $9=$ No need for improvement)

For this question, "environmental sustainability" is defined as sustained efforts to reduce one's carbon footprint, amount of pollution, consumption of resources such as water, and to engage in environmentally responsible activities such as recycling, composting, etc.

\section{Mean $=4.91$ Standard deviation $=\mathbf{2 . 1 0}$}

\section{Conflicts of Interest}

The authors declare no conflict of interest.

\section{References}

1. May, J.W.; Matila, M. Plugging in: A Stakeholder's Guide for Public Electric-Vehicle Charging Infrastructure; Rocky Mountain Institute: Snowmass, CO, USA, 2009.

2. What the World Needs to Watch. Available online: http://co2now.org (accessed on 24 June 2014).

3. Goldin, E.; Erickson, L.; Natarajan, B.; Pahwa, A. Solar Powered Charge Stations for Electric Vehicles. Environ. Progress Sustain. Energy 2014, 33, 1298-1308.

4. TST Issue Brief: Sustainable Transport. Available online: http://sustainabledevelopment.un.org/ content/documents/2634Issues $\% 20$ Brief $\% 20$ on\%20Sustainable\%20Transport_FINAL_21_Nov.pdf (accessed on 24 June 2014).

5. Erickson, L.E.; Boguski, T.; Babcock, M.W.; Leven, B.A.; Pahwa, A.; Brase, G.L.; Griswold, W.; Kramer, K.; Miller, R.D. Community Infrastructure for the Electrification of Transportation. Available online: http://www.smartgrowth.org/nationalconversation/papers/Erickson_SGN\%20 Natl_Conv_Paper_Electrification_of_Transport.6-22-2012.pdf (accessed on 10 June 2014).

6. Williams, J.H.; DeBenedictis, A.; Ghanadan, R.; Mahone, A.; Moore, J.; Morrow, W.R., III; Price, S.; Torn, M.S. The technology path to deep greenhouse gas emissions cuts by 2050: The pivotal role of electricity. Science 2012, 335, 53-59.

7. About K-State. Available online: http://www.k-state.edu/about/ (accessed on 10 July 2014).

8. U.S. Department of Energy. Electric Power Monthly with Data for November 2013. Retrieved from U.S. Energy Information Administration Website. Available online: http:/www.eia.gov/electricity/ monthly/current_year/january2014.pdf (accessed on 13 July 2014).

9. Weekly Retail Gasoline and Diesel Prices. U.S. Energy Information. Available online: http://www.eia.gov/dnav/pet/pet_pri_gnd_dcus_nus_w.htm (accessed on 10 June 2014). 
10. Find and Compare Cars. Available online: http:/www.fueleconomy.gov/feg/findacar.shtml (accessed on 13 June 2014).

11. Fuel Economy Guide. US Department of Energy. Available online: http://www.fueleconomy.gov/ feg/pdfs/guides/FEG2013.pdf (accessed on 22 June 2014).

12. Chang, D.; Erstad, D.; Lin, E.; Rice, A.F.; Goh, C.T.; Tsao, A.A.; Snyder, J. Financial Viability of Non-Residential Electric Vehicle Charging Stations; Luskin Center for Innovation: Los Angeles, CA, USA, 2012.

13. Focus Electric. Available online: http:/www.ford.com/cars/focus/trim/electric/ (accessed on 16 July 2014).

14. Nickel. Average Price of a New Car? Available online: http://www.forbes.com/sites/moneybuilder/ 2012/05/10/average-price-of-a-new-car/ (accessed on 10 May 2012).

15. Installing a Charging Station at a Commercial or Employee Parking Lot [Pamphlet]. Available online: http://www.psrc.org/assets/3967/Draft_Fact_Sheet.Commercial.051110.GD.pdf (accessed on 24 July 2014).

16. Barter, P. "Cars are Parked $95 \%$ of the Time." Let's Check! Available online: http://www.reinventingparking.org/2013/02/cars-are-parked-95-of-time-lets-check.html (accessed on 10 July 2014).

17. Tsoutsos, T.; Frantzeskaki, N.; Gekas, V. Environmental impacts from the solar energy technologies. Energy Policy 2005, 33, 289-296.

18. Parkinson, G. Obama Sends a Shock through Abbott's Energy Ideals. Available online: http://reneweconomy.com.au/2014/run-abbott-run-53988 (accessed on 3 June 2014).

19. Mets, K.; Verschueren, T.; Haerick, W.; Develder, C.; de Turck, F. Optimizing Smart Energy Control Strategies for Plug-in Hybrid Electric Vehicle Charging. Network Operations and Management Symposium Workshops (NOMS Wksps), 2010 IEEE/IFIP. Available online: http://dx.doi.org/10.1109/NOMSW.2010.5486561 (accessed on 3 July 2014).

20. Cutler, S.A.; Schmalberger, B.; Rivers, C. An Intelligent Solar Ecosystem with Electric Vehicles. Electric Vehicle Conference (IEVC), 2012 IEEE International. Available online: http://dx.doi.org/10.1109/IEVC.2012.6183168 (accessed on 17 June 2014).

21. Erickson, L. Third Report on the Installation of Shaded Parking Lot Structures with Integrated Photovoltaic Power Systems at Kansas State University. Available online: https://www.engg.ksu.edu/ chsr/files/chsr/sustainability/docs/ParkingLot3rdReport2011.pdf (accessed on 5 June 2014).

22. Morton, J. Plug into EV Charging Stations. Buildings 2012, 106, $28-31$.

23. Third-Party Solar Financing. Available online: http://apps3.eere.energy.gov/greenpower/onsite/ solar_financing.shtml (accessed on 9 June 2014).

24. Corcoran, B.; Golden, D.P.; Larson, K.; Schneider, S. Evs with Pvs: Analysis of Electric Vehicle Integration at Stanford University Using Solar Pv Panels. Available online: http://web.stanford.edu/ bethanyc/Papers/AASHE_EVs\%20with\%20PVs_FINAL.pdf (accessed on 11 June 2014).

25. Why Parking Meters should be Outlawed. Available online: http://www.taphilo.com/tom/ parkingmeters.shtml (accessed on 3 June 2014). 
26. Masoum, A.S.; Deilami, S.; Moses, P.S.; Abu-Siada, A. Impacts of Battery Charging Rates of Plug-In Electric Vehicle on Smart Grid Distribution Systems. Smart Grid Technologies Conference Europe (ISGT Europe), 2010 IEEE PES, 1,6,11-13. Available online: http://www.cricte2004.eletrica.ufpr.br/anais/IEE_ISGT_2010/2047502.pdf (accessed on 17 July 2014).

27. Kelly, R. Plug-in Vehicle Sales Roundup. Plug in America. Available online: https://org.salsalabs.com/o/2711/t/0/blastContent.jsp?email_blast_KEY=1300492 (accessed on 25 June 2014).

28. Gas Station Statistics. Available online: http://www.statisticbrain.com/gas-station-statistics/ (accessed on 24 June 2014).

29. Number of vehicles registered in the United States from 1990 to 2012 (in 1000 s). Available online: http://www.statista.com/statistics/183505/number-of-vehicles-in-the-united-states-since-1990/ (accessed on 24 June 2014).

30. Road Trips Made Easy. Available online: http://www.teslamotors.com/supercharger (accessed on 16 July 2014).

31. Sign Up for an NRG eVgo Plan. Available online: http://www.nrgevgo.com/charging-plans-bymarket/ (accessed on 2 July 2014).

32. Garthwaite, J. Coulomb to Deploy 4600 Electric Car Charge Spots Thanks to DOE. Available online: http://gigaom.com/2010/06/02/coulomb-to-deploy-4600-electric-car-charge-spots-thanksto-doe (accessed on 17 June 2014).

33. Solar Investment Tax Credit (ITC). Available online: http://www.seia.org/policy/finance-tax/solarinvestment-tax-credit (accessed on 13 July 2014).

34. Financial Incentives. Retrieved from Database of State Incentives for Renewables and Efficiency. http://www.dsireusa.org/incentives/allsummaries.cfm?State=us\&re=1\&ee=1 (accessed on 13 July 2014).

35. DSIRE. Retrieved from Database of State Incentives for Renewables and Efficiency. http://www.dsireusa.org/solar/ (accessed on 13 July 2014).

36. Davis, T. Charge Your Ride: University Installs Electric Vehicle Charging Station. Available online: http://www.kstate.edu/media/newsreleases/jan13/station13013.html (accessed on 1 July 2014).

37. Parking Permit Prices. Available online: http://www.k-state.edu/parking/permits/permitprices.html (accessed on 11 July 2014).

38. Maehlum, M.A. The Real Lifespan of Solar Panels. Available online: http://energyinformative.org/ lifespan-solar-panels/ (accessed on 13 July 2014).

39. Campus Master Plan Update Task Force. 2025 Campus Master Plan. Available online: http://www.k-state.edu/planning/master_plans/2025_plan/(accessed on 18 July 2014).

40. U.S. Department of Labor. American Time Use Survey- 2013 Results; U.S. Department of Labor: Washington, DC, USA, 2014.

41. Herron, D. The Business Model for Solar-Powered Electric Car Charging. Available online: http://www.plugincars.com/solar-powered-electric-car-charging-business-model-127710.html (accessed on 15 July 2014).

42. NRG's eVgo Charging Stations Hope to Catch the Eyes of Texas. Chatham: Newstex. Available online: http://search.proquest.com.er.lib.k-state.edu/docview/861143581?accountid=11789 (accessed on 10 July 2014). 
43. Most States Have Renewable Portfolio Standards. Available online: http://www.eia.gov/ todayinenergy/detail.cfm?id=4850 (accessed on 13 July 2014).

44. Renewable and Alternative Energy Portfolio Standards. Available online: http://www.c2es.org/ node/9340 (accessed on 13 July 2014).

45. About. Available online: http://goo.gl/hbIC4i (accessed on 13 July 2014).

46. HEB, Walmart and Sam's Club to Host Electric Vehicle Charging Stations. Available online: http://www.greenretaildecisions.com/news/2011/08/11/heb-walmart-and-sams-club-to-hostelectric-vehicle-charging-stations (accessed on 13 July 2014).

47. Austin Energy surpasses 10,000TH plug-in Charge at Public Stations. US Fed News Service, Including US State News. Available online: http://search.proquest.com.er.lib.k-state.edu/docview/ 1282750492?accountid=11789 (accessed on 10 July 2014).

48. Andersen, P.H.; Mathews, J.A.; Rask, M. Integrating private transport into renewable energy policy: The strategy of creating intelligent recharging grids for electric vehicles. Energy Policy 2009, 37, 2481-2486.

49. Vonderschmitt, K. State Utilities Law and Electric Vehicle Charging Stations. Available online: http://knowledgecenter.csg.org/kc/content/state-utilities-law-and-electric-vehicle-charging-stations (accessed on 21 July 2014).

50. Mavridis, M. Parking Lot Aesthetic and the City Image: A Practicum Document. (Order No. MQ90482, the University of Manitoba (Canada)). ProQuest Dissertations and Theses. Available online: http://search.proquest.com.er.lib.k-state.edu/docview/305089741 ?accountid=11789. (305089741) (accessed on 23 July 2014).

51. Mayor Coleman Unveils New Solar-Powered Electric Car Charging Stations in Como Park, First of Their Kind in Minnesota. Available online: http://mccollum.house.gov/press-release/ mayor-coleman-unveils-new-solar-powered-electric-car-charging-stations-como-park-first (accessed on 21 July 2014).

52. U.S. Department of Transportation. FAQs. Available online: http://transerve.dot.gov/faq.html (accessed on 25 July 2014).

53. Surpure, J.S. Heat-Related Illness and the Automobile. Ann. Emerg. Med. 1982, 11, 263-266.

54. Gas Pump Advertising. Available online: http://www.allovermedia.com/our-solutions/gas-pump/ (accessed on 29 July 2014).

55. Levy, J.I.; Dilwali, K.M. Economic incentives for sustainable resource consumption at a large university. J. Sustain. High. Educ. 2000, 1, 252-266.

56. Vehicle Technologies Office: EV Everywhere Workplace Charging Challenge. Available online: http://energy.gov/eere/vehicles/vehicle-technologies-office-ev-everywhere-workplace-chargingchallenge (accessed on 21 September 2014).

57. Retail Light-Vehicle Sales Strengthening in March. Available online: http://www.jdpower.com/ press-releases/2014-march-automotive-forecast (accessed on 21 September 2014).

58. Conrad, E.; Aberg, W.J.P. Validity of parking meter ordinances. Va. Law Rev. 1943, 29, 617-624.

59. U.S. EPA. Carbon Pollution Emission Guidelines for Existing Stationary Sources: Electric Utility Generating. Available online: https://www.federalregister.gov/ (accessed on 4 October 2014). 
60. Johnson, R.M. Smart Grid: Carbon and Economic Implications for Colorado. (Order No. 3403932, University of Colorado at Boulder). ProQuest Dissertations and Theses, 153. Available online: http://search.proquest.com.er.lib.k-state.edu/docview/507901067?accountid=11789. (507901067) (accessed on 4 October 2014).

61. Uda, R. UCSD Installs First Electric Vehicle Charging Stations. The Guardian. Available online: http:/ucsdguardian.org/2012/10/8/ucsd-installs-first-electric-vehicle-charging-stations/ (accessed on 6 October 2014).

62. Electric Vehicles. Available online: http://www.sullivansolarpower.com/solar-power/electricvehicles (accessed on 3 October 2014).

63. Fast Charging Along the Highway. Available online: http://www.fastned.nl/en (accessed on 7 October 2014).

64. Use of Solar Powered Electric Vehicle Charging Stations at San Diego Zoo on the Rise [Blog post]. Available online: http://cleantechsandiego.wordpress.com/2014/08/26/use-of-solar-powered-electricvehicle-charging-stations-at-san-diego-zoo-on-the-rise/ (accessed on 7 October 2014).

65. Mariotti, S.; Glackin, C. Entrepreneurship \& Small Business Management; Prentice Hall: Upper Saddle River, NJ, USA, 2012.

66. Teece, D.J. Business models, business strategy, and innovation. Long Range Plan. 2010, 43, 172-194.

(C) 2014 by the authors; licensee MDPI, Basel, Switzerland. This article is an open access article distributed under the terms and conditions of the Creative Commons Attribution license (http://creativecommons.org/licenses/by/4.0/). 